\title{
Analisis Sistem Antrian di Dinas Kependudukan dan Pencatatan Sipil Kabupaten Karawang
}

\author{
Gina Khoirunnisa ${ }^{1)}$, Nelly Martini ${ }^{2)}$ \\ 1), 2) Manajemen, Universitas Singaperbangsa Karawang \\ Jl. HS. Ronggowaluyo, Sirnabaya, Telukjambe Timur \\ Email: gina.khoirunnisa16159@student.unsika.ac.id ${ }^{1)}$,nellymartini@yahoo.co.id ${ }^{2}$
}

\begin{abstract}
This study aims to clarify the phenomenon of the use of service facilities and find the level of optimization of the queuing system and total costs. The queuing system is a process related to waiting for people to get services efficiently.The study was conducted at the birth certificate registration queue system using 2 (two) facilities at the Karawang Regency Population and Civil Registry Office using the multiple lane queue model $(M / M / S)$. the population in this study were visitors who came to the birth certificate registration counter. The data collection time for one month is July 2019 at 10:00 - 11:00 WIB. Based on the results of research, simulations, and discussion it can be concluded that the actual condition queuing system in the Karawang Regency's Population and Civil Registration Service uses 2 (two) lane facility counters, the optimal queuing system at the Karawang Regency's Population and Civil Registration Service uses 3 (three) counter facilities following the $M / M / S$ queuing model. the cost efficiency obtained is Rp. 75,531, - per hour or Rp. 13,897,667 per month with a percentage of $75 \%$.
\end{abstract}

Keywords: Queue System, Total Cost, M/M/S Model

\begin{abstract}
ABSTRAK
Penelitian ini bertujuan untuk kejelasan fenomena penggunaan fasilitas pelayanan dan menemukan tingkat optimalisasi sistem antrian dan biaya total. Sistem antrian merupakan suatu proses yang berkaitan dengan menunggunya orang untuk mendapatkan pelayanan secara efisien. Penelitian dilakukan pada sistem antrian loket pendaftaran akta kelahiran menggunakan 2 (dua) fasilitas di Dinas Kependudukan dan Pencatatan Sipil Kabupaten Karawang menggunakan model antrian jalur berganda $(M / M / S)$. populasi dalam penelitian ini adalah pengunjung yang datang ke loket pendaftaran akta kelahiran. Waktu pengambilan data selama satu bulan yaitu Juli 2019 pada jam 10.00 - 11.00 WIB. Berdasarkan hasil penelitian, simulasi, dan pembahasan dapat disimpulkan bahwa sistem antrian kondisi actual di Dinas Kependudukan dan Pencatatan Sipil Kabupaten Karawang menggunakan 2 (dua) jalur fasilitas loket, sistem antrian optimal di Dinas Kependudukan dan Pencatatan Sipil Kabupaten Karawang menggunakan 3 (tiga) fasilitas loket mengikuti model antrian M/M/S. efisiensi biaya yang didapatkan yaitu Rp. 75.531,- per jam atau Rp. 13.897.667,- per bulan dengan persentase sebesar $75 \%$.
\end{abstract}

Kata Kunci: Sistem Antrian, Biaya Total, Model M/M/S

\section{Pendahuluan}

Laju pertumbuhan penduduk adalah perubahan jumlah tingkat pertambahan penduduk di suatu wilayah tertentu disetiap tahunnya. Adanya pertambahan penduduk karena adanya peningkatan angka fertilitas. Fertilitas atau yang sering dikenal dengan kelahiran dapat diartikan sebagai hasil reproduksi yang nyata dari penduduk (actual reproduction performance) atau jumlah anak hidup yang dilahirkan oleh seorang atau sekelompok perempuan.

Berdasarkan gambar 1 tersebut angka kelahiran menurun yaitu untuk umur 0-4 tahun, sedangkan untuk umur 5-19 tahun mengalami kenaikan dan stabil karena adanya angka kelahiran yang tinggi sebelum adanya program pemerintah Kampung Keluarga Berencana (KKB). Setiap anak yang lahir perlu adanya identitas sah dan diakui kewarganegaraannya, maka anak tersebut harus memiliki akta kelahiran sebelum menginjak umur
17 (tujuh belas tahun) untuk memiliki Kartu Tanda Penduduk (KTP).

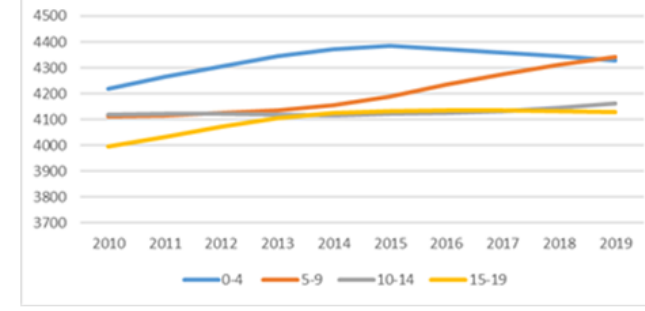

Gambar 1. Proyeksi Penduduk Jawa Barat Berdasarkan Kelompok Umur 0-19 Tahun

Salah satu kantor pelayanan publik yang memberikan pelayanan mengenai data kependudukan seperti data kelahiran, perkawinan, percerian, dan kematian di Indonesia adalah Kantor Kependudukan dan Pencatatan Sipil. Berdasarkan Keputusan MENDAGRI No. 54 Tahun 1983 Kantor Kependudukan dan Pencatatan 
Sipil adalah perangkat wilayah yang membantu Bupati/ Walikotamadya Kepala Daerah Tinglat II. Selaku Wakil Pemerintah Pusat dalam rangka pelaksanaan asas dekonsentrasi untuk melaksanakan kebijaksanaan catatan sipil di Daerah dan hanya satu-satunya pelaksanaan utama yang menangani urusan catatan sipil (Septiadi, 2019).

Berdasarkan Gambar 3., penduduk Karawang setiap tahunnya meningkat salah satunya karena bertambahnya angka kelahiran. Hal tersebut terlihat dari banyaknya masyarakat yang memohon pengajuan penerbitan akta kelahiran ke Kantor Dinas Kependudukan dan Pencatatan Sipil Kabupaten Karawang.

Terhitung mulai 1 Januari 2014, Pemerintah akan membebaskan biaya administrasi untuk pembuatan Kartu Tanda Penduduk (KTP), Kartu Keluarga (KK), akta kelahiran, dan akta kematian serta Kementrian dalam Negeri (Mendagri) menjelaskan bahwa semua penerbitan dokumen kependudukan dikeluarkan oleh Disdukcatpil di seluruh kabupaten/kota di Indonesia, jadi pemohon tidak perlu ke pengadilan untuk mendapatkan Akta Kelahiran (brs, 2013).

Pembebasan biaya dalam penerbitan dokumen kependudukan tersebut mempengaruhi pemohon untuk mengunjungi kantor Disdukcatpil Kab. Karawang secara langsung ataupun online. Banyaknya orang mengunjungi Disdukcatpil Kab. Karawang mengharuskan semua orang untuk membudayakan mengantri. Antrian dapat terjadi karena pengunjung yang datang ke suatu pelayanan melebihi kapasitas pelayanan yang telah ada (Arum, Sugito, \& Wilandari, 2014).

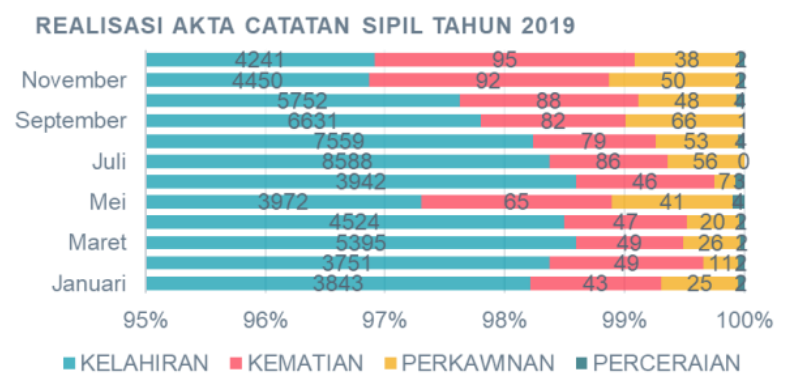

Gambar 2. Realisasi Akta Catatan Sipil di Disdukcatpil Kab. Karawang Tahun 2019

Berdasarkan gambar 2. menunjukkan pemohon akta paling banyak ada pada loket Akta kelahiran yang melonjak pada pertengahan tahun yakni bulan Juli 2019 sebanyak 8.588 pendaftar, dengan 8.131 orang yang daftar secara langsung ke kantor dan 600 melalui online. Atau pemohon yang datang secara langsung ke loket pendaftaran akta kelahiran sebesar $94 \%$ dan pemohon yang melalui online sebesar $6 \%$.

Struktur jalur antrian yang diterapkan pada loket pendaftaran akta kelahiran di Disdukcatpil Kab. Karawang yaitu memiliki satu jalur antrian yang dilayani oleh dua loket yakni loket A dan loket B. Sumber kedatangan pemohon secara acak tidak dapat ditentukan dengan waktu yang pasti, untuk pengambilan nomor antriannya sudah menggunakan fasilitas elektronik dimana pemohon yang pertama datang akan dilayani terlebih dahulu (First Come First Served) oleh loket yang kosong. Setelah pelayanan selesai maka pemohon bisa meninggalkan fasilitas tersebut. Sedangkan standar waktu yang diterapkan oleh loket pendaftaran akta kelahiran di Disdukcatpil Kab. Karawang yaitu dua menit.

Adapun permasalahan yang terjadi salah satunya yaitu pemohon yang tidak membawa dokumen persyaratan yang telah ditentukan. Kemudian, adanya perbedaan antara nama yang tercantum dengan Kartu Keluarga dengan Surat Nikah dan sebagainya. Berdasarkan permasalahan tersebut secara langsung sudah melebihi standar waktu yang telah ditentukan dan dapat menyebabkan penumpukan antrian apabila pengunjung pada hari tersebut sedang banyak. Berikut layanan harian pendaftaran akta kelahiran di Disdukcatpil Kab. Karawang.

Tabel 1. Daily Service Entry Pendaftaran Akta Kelahiran Dinas Kependudukan dan Pencatatan Sipil Kab. Karawang Periode Juli 2019

\begin{tabular}{|c|c|c|c|c|}
\hline \multirow[b]{2}{*}{ Hari } & \multirow[b]{2}{*}{ Tanggal } & \multicolumn{3}{|c|}{ Jumlah Pendaftar } \\
\hline & & Harian & Terlayani & $\begin{array}{l}\text { Tidak } \\
\text { Terlayani }\end{array}$ \\
\hline Senin & $1 / 07 / 2019$ & 357 & 303 & 54 \\
\hline Selasa & $2 / 07 / 2019$ & 322 & 312 & 10 \\
\hline Rabu & $3 / 07 / 2019$ & 377 & 365 & 12 \\
\hline Kamis & $4 / 07 / 2019$ & 592 & 552 & 40 \\
\hline Jumat & $5 / 07 / 2019$ & 302 & 279 & 23 \\
\hline Senin & $8 / 07 / 2019$ & 226 & 186 & 40 \\
\hline Selasa & $9 / 07 / 2019$ & 471 & 451 & 20 \\
\hline Rabu & $10 / 07 / 2019$ & 512 & 467 & 45 \\
\hline Kamis & $11 / 07 / 2019$ & 359 & 355 & 4 \\
\hline Jumat & $12 / 07 / 2019$ & 396 & 376 & 20 \\
\hline Senin & $13 / 07 / 2019$ & 478 & 425 & 53 \\
\hline Selasa & $16 / 07 / 2019$ & 345 & 343 & 2 \\
\hline Rabu & $17 / 07 / 2019$ & 422 & 416 & 6 \\
\hline Kamis & $18 / 07 / 2019$ & 487 & 452 & 35 \\
\hline Jumat & $19 / 07 / 2019$ & 291 & 282 & 9 \\
\hline Senin & $22 / 07 / 2019$ & 279 & 232 & 47 \\
\hline Selasa & $23 / 07 / 2019$ & 223 & 220 & 3 \\
\hline Rabu & $24 / 07 / 2019$ & 388 & 355 & 33 \\
\hline Kamis & $25 / 07 / 2019$ & 272 & 262 & 10 \\
\hline Jumat & $26 / 07 / 2019$ & 216 & 212 & 4 \\
\hline Senin & $29 / 07 / 2019$ & 587 & 515 & 72 \\
\hline Selasa & $30 / 07 / 2019$ & 322 & 321 & 1 \\
\hline Rabu & $31 / 07 / 2019$ & 364 & 324 & 40 \\
\hline Total & & 8.588 & 8.045 & 543 \\
\hline
\end{tabular}

Berdasarkan tabel 1 tersebut jumlah pemohon yang datang untuk mengentry antrian sebanyak 8.588 orang, sedangkan yang terlayani hanya 8.045 dan sisanya keluar dari antrian. Penulis juga mengamati gedung akta tersebut sangatlah sempit karena dalam satu gedung terdapat beberapa fasilitas diantaranya 2 (dua) loket pendaftaran akta kelahiran, 1 (satu) loket akta kematian, perkawinan dan perceraian dan 1 (satu) loket pengambilan akta kelahiran. Kursi tempat menunggu yang tersedia hanyalah untuk 30 (tiga puluh) orang sehingga tidak sedikit orang yang berdiri karena tidak kebagian tempat duduk, juga terdapat pelayanan kurang efektif karena ramai oleh orang-orang yang mengobrol. 
Selain itu, ada pula pemohon yang tidak mengikuti Standar Operasional Prosedur (SOP) sistem antrian yang telah diterapkan, mereka tiba-tiba datang ke loket yang bersangkutan namun tidak mengambil nomor antrian. Hal tersebut secara tidak langsung telah menyebabkan antrian semakin lama.

Suatu hal menyenangkan apabila seorang pengunjung mendapat pelayanan tanpa harus menunggu, dan keseimbangan antara jumlah kapasitas pelayanan dengan jumlah konsumen yang akan dilayani harus diperhatikan agar tidak terjadi suatu antrian panjang (Botutihe, Sumarauw, \& Karuntu, 2018).

Berdasarkan beberapa permasalahan yang telah dipaparkan diatas merupakan masalah yang sedang dihadapi oleh Disdukcatpil Kab. Karawang dan perlu menemukan jalan keluarnya. melihat proses antrian tersebut dapat dikatakan bahwa pemohon sangat ingin mendapatkan pelayanan yang cepat dan tepat pada suatu fasilitas layanan. Oleh karena itu, Disdukcatpil Kab. Karawang harus mengambil keputusan agar tidak terjadi antrian yang sangat lama. Jika waktu yang digunakan untuk mengantri sangatlah lama, maka pemohon akhirnya akan keluar dari sistem antrian.

Permasalahan yang dikemukakan diatas tersebut sejalan dengan penelitian Riana Sinaga dan Devilia Sari mengenai Analisis Sistem Antrian di Dinas Kependudukan Dan Pencatatan Sipil Kota Bandung: Studi pada Loket Pelayanan Pencatatan dan Penerbitan Akta Kelahiran Bayi Berumur 0-60 Hari, yang bertujuan untuk menganalisis sistem antrian pada pelayanan tersebut dan beberapa sistem lain yang dipertimbangkan untuk dapat memperbaiki waktu pelayanan (Sinaga \& Sari, 2015).

\section{Landasan Teori \\ Manajemen}

\section{Pengertian Manajemen}

Manajemen (pengelolaan) adalah hal yang dilakukan oleh para manajer. Manajemen melibatkan kegiatan koordinasi dan pengawasan terhadap pekerjaan orang lain, sehingga pekerjaan tersebut dapat diselesaikan secara efektif dan efisien serta bertanggung jawab (Robbins, Coulter, Sabran, \& Hardani, 2010).

\section{Fungsi - Fungsi Manajemen}

Adapun 4 (empat) fungsi manajemen yang dapat membantu perusahaan untuk mencapai tujuannya (Robbins, Coulter, Sabran, \& Hardani, 2010), yaitu :
a. Planning (Perencanaan)
b. Organizing (Pengkoordinasian)
c. Leading (Memimpin)
d. Controlling (Pengawasan)

\section{Manajemen Operasi}

\section{Pengertian Manajemen Operasi}

Manajemen operasi merupakan suatu kegiatan dalam manajemen yang mempunyai fungsi untuk menghasilkan suatu produk sesuai dengan standar yang ditetapkan berdasarkan harapan konsumen, menggunakan teknik produksi yang seefisien mungkin, seperti memilih lokasi produksi hingga produksi akhir yang dihasilkan dalam proses produksi (Mardalena, 2017)

\section{Fungsi Manajemen Operasi}

Fungsi dari pengaplikasian ilmu Manajemen Operasi (Akhmad, 2018) yaitu adalah:
a. Proses pengolahan,
b. Jasa-jasa penunjang.
c. Perencanaan,
d. Pengendalian dan pengawasan,

\section{Riset Operasi}

\section{Pengertian Riset Operasi}

Menurut Miller dan MK. Star riset operasi merupakan seperalatan manajemen yang menyatukan matematika, ilmu pengetahuan, dan logika dalam kerangka pemecahan masalah yang dihadapi perusahaan, sehingga permasalahan tersebut dapat dipecahkan secara optimal (Syaifuddin, 2011).

\section{Model Riset Operasi}

Model riset operasi terbagi kedalam beberapa jenis (Meflinda \& Mahyarni, 2011), diantaranya adalah sebagai berikut.
a. Linier programming
b. Metode Transportasi
c. Metode Penugasan
d. Teori Network
e. Teori Keputusan
f. Teori Permainan
g. Teori Antrian
h. Teori Penggantian

\section{Sistem Antrian}

\section{Pengertian Sistem Antrian}

Krajewski et al dalam buku Operations Management: Processes and Supply Chains (2019:263) menjelaskan bahwa Antrian merupakan satu atau lebih customers yang menunggu dalam suatu sistem untuk mendapatkan pelayanan (Krajewski, Malhotra, \& Ritzman, 2019).

\section{Karakteristik Sistem Antrian}

Karakteristik sistem antrian ada tiga bagian (Heizer \& Render, 2015)diantaranya adalah sebagai berikut.

a. Kedatangan atau input pada sistem. Ini memiliki karakteristik diantaranya yaitu sumber populasi, perilaku, dan pola kedatangan.

b. Disiplin antrian. Karakteristik ini meliputi terbatas atau tidaknya suatu panjang antrian dan disiplin dari orang atau barang yang berada dalam sistem.

c. Fasilitas jasa. Karakteristiknya meliputi desain sistem dan waktu pelayanan.

\section{Model-Model Antrian}

Antrian terbagi pada beberapa jenis dan umum terjadi (Heizer \& Render, 2015) yaitu sebagai berikut.

a. Model A (M/M/1): Model Antrian Server Tunggal atau Single Phase Queuing System. Dalam situasi ini, kedatangan membentuk satu jalur tunggal untuk dilayani oleh stasiun tunggal. 
b. Model B (M/M/S): Model Antrian Jalur Berganda atau Multiple Channel Queuing System. Pada sistem antrian model ini, terdapat dua atau lebih jalur atau stasiun pelayanan yang tersedia untuk menangani para pengunjung yang datang. Asumsi bahwa pengunjung yang menunggu pelayanan membentuk satu jalur dan akan dilayani pada stasiun pelayanan yang tersedia pertama kali pada saat itu

c. Model C (M/D/1): Antrian Jalur Tunggal dengan Kedatangan Berdistribusi Poisson dan Waktu Pelayanan Konstan.

d. Model D: Antrian Jalur Tunggal dengan Populasi Terbatas

\section{Biaya Sistem Antrian}

Menentukan biaya tidak langsung (indirect cost) pada orang-orang yang menunggu, dan biaya langsung (direct cost) untuk penyedia fasilitas, maka tujuan dasar antrian adalah meminimasi kedua biaya tersebut (Budiasih, 2015).

\section{Metodologi}

Penelitian ini menggunakan metode penelitian kuantitatif. Metode kuantitatif merupakan metode penelitian yang berlandaskan pada filsafat positivisme, digunakan untuk meneliti pada populasi atau sampel tertentu. Filsafat positivisme memandang realitas/gejala/fenomena itu dapat dikasifikasikan, relatif tetap, konkrit, termati, terukur dan hubungan gejala bersifat sebab akibat (Sugiyono, 2012).

Pada penelitian ini menggunakan penelitian kuantitatif yang menggambarkan keadaan sistem antrian pada loket pedaftaran akta kelahiran di Disdukcatpil Kab. Karawang berdasarkan hasil perhitungan rumus antrian dengan model Multi Channel Single Phase (M/M/s), dalam hal ini situasi kedatangan antrian pemohon membentuk sistem jalur tunggal dan dilayani oleh dua loket yang sama yaitu pendaftaran akta kelahiran.

Adapun analisis data yang digunakan dalam penelitian kuantitatif ini adalah statistik deskriptif. Statistik deskriptif merupakan statistik yang digunakan untuk menganalisis data dengan cara mendeskripsikan atau menggambarkan data yang telah terkumpul sebagaimana adanya tanpa bermaksud membuat kesimpulan yang berlaku untuk umum atau generalisasi (Sugiyono, 2012).

\subsection{Data}

Populasi dalam penelitian ini adalah seluruh pemohon yang datang pada loket pendaftaran akta kelahiran Disdukcatpil Kab. Karawang di bulan Juli 2019 sebanyak 8.131 orang. Slovin.

Sedangkan penentuan sampel menggunakan rumus

$$
\begin{aligned}
& n=\frac{N}{N(d)^{2}+1} \\
& \text { Keterangan : } \\
& \mathrm{n}=\text { sampel } \\
& \mathrm{N}=\text { populasi }
\end{aligned}
$$

$$
\begin{aligned}
& \mathrm{d}=\text { nilai presisi } 95 \% \text { atau sig. }=0,05 \\
& \text { sehingga dapat diperoleh }: \\
& n=\frac{8.131}{8.131(0,05)^{2}+1} \\
& n=\frac{8.131}{21,33}=381,2 \approx 381
\end{aligned}
$$

Dari perhitungan diatas, ditemukan bahwa jumlah sampel minimal agar penelitian ini valid yaitu sebanyak 381 orang.

Teknik yang digunakan dalam Probability sampling ini yaitu Simple Random Sampling, yang memiliki ciri utama dari sampling ini adalah setiap unsur dari keseluruhan populasi mempunyai kesempatan yang sama untuk dipilih (Hardani, 2020).

Simple random sampling ini digunakan untuk mencari data waktu pelayanan pemohon ke loket pendaftaran akta kelahiran yaitu dengan mengambil sampel sebanyak 381 orang pemohon secara acak dengan membagi sampel perhari sebanyak 17 pemohon selama 23 hari pada jam tersibuk yaitu pukul $10.00-11.00$ WIB pada bulan Juli 2019 .

\subsection{Metode Analisis}

menganalisis data dalam penelitian yang berkaitan dengan pendaftaran akta kelahiran di Disdukcatpil Kab. Karawang adalah sebagai berikut.

Langkah pertama, melakukan persiapan yang berhubungan dengan penelitian termasuk melakukan pengujian keabsahan data.

Langkah kedua, mengumpulkan data-data yang akan diolah dalam penelitian yaitu :

a. Waktu kedatangan pengunjung

b. Waktu pelayanan pengunjung

c. Lamanya pengunjung menunggu antrian

d. Lamanya proses pelayanan

Langkah ketiga, menganalisis data yang telah dikumpulkan dengan menggunakan model antrian M/M/S Langkah keempat, menghitung biaya menunggu $\mathrm{E}\left(\mathrm{C}_{\mathrm{w}}\right)$, biaya fasilitas $\mathrm{E}\left(\mathrm{C}_{\mathrm{s}}\right)$ dan biaya total.

a. Menghitung besarnya biaya menunggu $E\left(C_{w}\right)$ dengan rumus:

$$
E\left(c_{w}\right)=\overline{n_{t}} c_{w}
$$

b. Menghitung besarnya biaya fasilitas $\mathrm{E}(\mathrm{Cs})$ dengan rumus:

$$
E\left(C_{s}\right)=S c_{s}
$$

c. Menghitung biaya total $\mathrm{E}(\mathrm{Ct})$ dengan rumus:

$$
E\left(C_{t}\right)=E\left(C_{s}\right)+E\left(C_{w}\right)=S c_{s}+\overline{n_{t}} c_{w}
$$

Langkah kelima, melakukan perhitungan dasar primer yang telah diperoleh dalam penelitian akan dilakukan dengan cara manual dan menggunakan software POM-QM for windows.

Langkah keenam, melakukan analisa dan interpretasi terhadap hasil output guna untuk menentukan jumlah loket pelayanan yang optimal pada masing-masing kondisi sehingga perusahaan dapat memberikan kinerja yang optimal juga dalam memberikan pelayanan kepada pemohon. 


\section{Hasil dan Pembahasan}

\section{Hasil Pengujian Keabsahan Data}

1. Uji Keseragaman Data

Uji keseragaman data bertujuan untuk mengetahui apakah data yang telah didapatkan telah berada pada batas kewajaran (seragam). Hasil uji keseragaman data dapat dilihat pada gambar berikut.

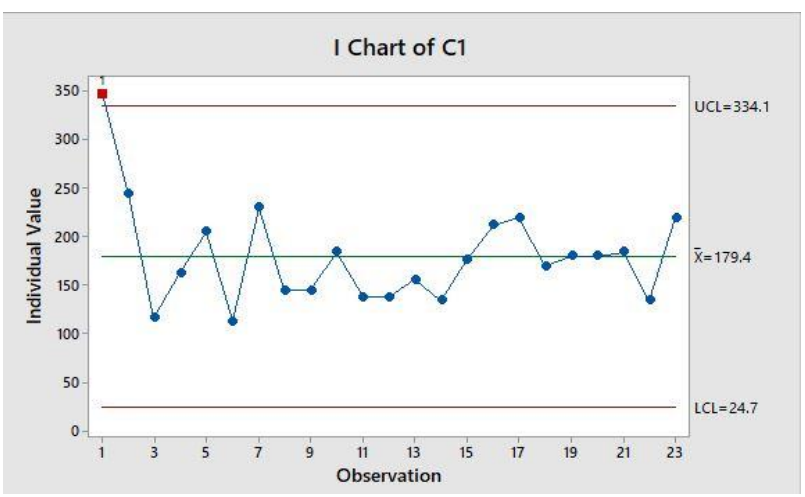

Gambar 3. Uji Keseragaman Data

Berdasarkan hasil uji keseragaman dapat dilihat bahwa data berada dalam batas kewajaran, yaitu dibawah batas kontrol atas (UCL) dengan nilai 334.1, di atas batas kontrol bawah (LCL) dengan nilai 24.7, dan nilai garis tengah (CL) adalah 179.4. Terdapat satu sampel yang berada di atas batas kontrol atas (UCL) akan tetapi data masih dapat dikatakan termasuk dalam kategori seragam. Uji data ini dilakukan dengan bantuan software Minitab versi 18 .

\section{Uji Kecukupan Data}

Uji kecukupan data dilakukan untuk mengetahui apakah data yang didapatkan sudah cukup untuk mewakili populasi yang diamati. Jika $\mathrm{N}>\mathrm{N}$ ' maka jumlah data yang didapatkan telah cukup mewakili populasi yang diteliti. Berikut hasil uji kecukupan data menggunakan rumus slovin

$$
\begin{aligned}
& n=\frac{N}{N(d)^{2}+1} \\
& \text { Keterangan }: \\
& \mathrm{n}=\text { sampel } \\
& \mathrm{N}=\text { populasi } \\
& \mathrm{d}=\text { nilai presisi } 95 \% \text { atau sig. }=0,05 \\
& \text { sehingga dapat diperoleh }: \\
& n=\frac{8.131}{8.131(0,05)^{2}+1} \\
& n=\frac{8.131}{21,33}=381,2 \approx 381
\end{aligned}
$$

Jumlah data observasi (N) lebih besar dari jumlah data minimum (n). Dapat disimpulkan bahwa data yang diperoleh sudah cukup mewakili populasinya.

\section{Uji Pola Distribusi Data}

Uji distribusi data dilakukan untuk mengukur apakah data kecepatan kedatangan masyarakat mengikuti pola distribusi Poisson dan data kecepatan pelayanan masyarakat mengikuti pola distribusi eksponensial atau terdistribusi secara acak. Hasil perhitungan distribusi Poisson dapat dilihat pada gambar 5 dan 6 dibawah.

Berdasarkan kedua hasil perhitungan uji distribusi diatas, kecepatan kedatangan masyarakat mengikuti pola distribusi Poisson yaitu 353,48 orang dan data kecepatan pelayanan masyarakat mengikuti pola distribusi eksponensial yaitu 179,53 detik, maka data antrian pendaftaran di loket akta kelahiran dapat dianalisis dengan menggunakan rumus antrian baku.

\section{One-Sample Kolmogorov-Smirnov Test}

\begin{tabular}{lll} 
& & Kedatangan \\
\hline $\mathrm{N}$ & & 23 \\
\hline Poisson Parameter & & 353.48 \\
\hline Most Extreme Differences & Absolute & .435 \\
\cline { 2 - 3 } & Positive & .435 \\
\cline { 2 - 3 } & Negative & -.391 \\
\hline Kolmogorov-Smirnov Z & & 2.088 \\
\hline Asymp. Sig. (2-tailed) & & .000 \\
\hline
\end{tabular}

a. Test distribution is Poisson.

b. Calculated from data.

Gambar 4. Uji Distribusi Poisson

\section{One-Sample Kolmogorov-Smirnov Test}

\begin{tabular}{lll}
\hline $\mathrm{N}$ & & Pelayanan \\
\hline Exponential parameter. $^{\text {a,b }}$ & Mean & 381 \\
\hline Most Extreme Differences & Absolute & .430 \\
\cline { 2 - 3 } & Positive & .164 \\
\cline { 2 - 3 } & Negative & -.430 \\
\hline Kolmogorov-Smirnov Z & & 8.388 \\
\hline Asymp. Sig. (2-tailed) & & .000 \\
\hline
\end{tabular}

a. Test Distribution is Exponential.

b. Calculated from data.

Gambar 5. Uji Distribusi Eksponensial

\section{Hasil Analisis Data}

1. Gambaran Antrian Loket Pendaftaran Akta Kelahiran di Dinas Kependudukan dan Pencatatan Sipil Kabupaten Karawang

Tingkat kedatangan merupakan banyaknya pengunjung yang datang untuk mendapatkan pelayanan pada fasilitas, dinyatakan dalam berapa banyak pengunjung (orang) dalam periode waktu tertentu. Tingkat kedatangan orang diasumsikan mengikuti distribusi poisson yaitu kedatangan yang tidak tergantung pada waktu dan tingkat kedatangan setiap harinya tidak sama. Dari pengumpulan data yang diperoleh data kedatangan selama 23 hari pada bulan Juli 2019 di loket pendaftaran akta kelahiran Disdukcatpil Kab. Karawang dan telah diolah menggunakan software SPSS yang terdapat pada gambar 5. dengan jumlah rata-rata harian sebanyak 353,48 orang 354 orang. Maka, rata-rata kecepatan kedatangan masyarakat $(\lambda)$ oleh server sebanyak 44 orang per jam. 
Pada saat memasuki bulan Juli 2019 jumlah masyarakat yang mengantri pada loket pendaftaran akta kelahiran meningkat, salah satunya dikarenakan mendekati waktu pendaftaran sekolah, sehingga jumlah masyarakat yang mengurus akta kelahiran meningkat. Dalam sepekan rata-rata hari senin dan kamis merupakan waktu kedatangan masyarakat yang paling banyak dan pada pukul 10.00 - 11.00 WIB merupakan waktu padat antrian.

Tingkat kemampuan (rata-rata) untuk melayani antrian dalam setiap kedatangan tidaklah sama dan selesai dengan waktu yang berbeda-beda. Untuk mengetahui waktu yang dibutuhkan untuk pelayanan setiap jamnya.

Berdasarkan gambar 6 diatas, dapat diketahui kemampuan pelayanan loket pendaftaran akta kelahiran di Disdukcatpil Kab. Karawang pada jam 10.00 - 11.00 WIB. Kemampuan pelayanan ini dihitung mulai dari pemanggilan, pengecekan kelengkapan data hingga penginputan data membutuhkan waktu 179,53 detik atau sama dengan 2,99 menit. Jadi, rata-rata kecepatan pelayanan $(\mu)$ oleh server adalah sebanyak 20 orang per jam.

Karakteristik sistem antrian yang ada pada loket pendaftaran akta kelahiran di Disdukcatpil Kab. Karawang dengan 2 (dua) jalur fasilitas pelayanan digambarkan sebagai berikut.

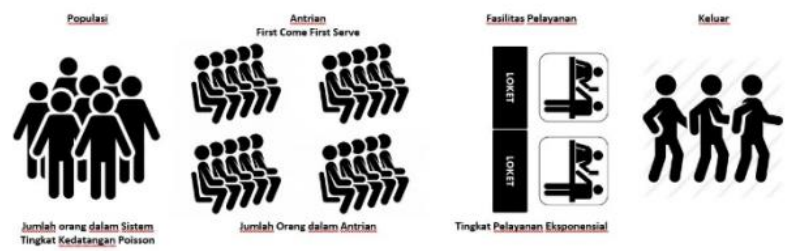

Gambar 6. Skema Antrian Loket Pendaftaran Akta Kelahiran

2. Penerapan Antrian Melalui Metode Teori Antrian di Loket Pendaftaran Akta Kelahiran Dinas

Kependudukan dan Pencatatan Sipil Kabupaten Karawang

Teori Antrian dengan Dua Fasilitas Pelayanan (Sebelum Simulasi)

Berdasarkan karakteristik pada model antrian, proses pelayanan pendaftaran akta kelahiran di Disdukcatpil Kab. Karawang memiliki dua fasilitas dengan satu tahap, maka dapat dianalisa menggunakan model antrian $\mathrm{M} / \mathrm{M} / \mathrm{S}$. Analisis model antrian dapat digunakan untuk mencari nilai-nilai steady kinerja dari loket pendaftaran akta kelahiran dengan 2 (dua) fasilitas yaitu sebagai berikut.

Tabel 2. Hasil Perhitungan Sistem Antrian dengan 2 Fasilitas Loket (Kondisi Sebelum Simulasi dengan Teori Antrian)

\begin{tabular}{|l|l|l|l|l|l|}
\hline $\begin{array}{l}\text { Periode } \\
\text { Waktu }\end{array}$ & $\mathrm{M}$ & $\lambda$ & $\mu$ & $P$ & $P_{0}$ \\
\hline \multirow{3}{*}{$\begin{array}{l}10.00- \\
11.00 \mathrm{WIB}\end{array}$} & 2 & 44 & 20 & $100 \%$ & $-0,04$ \\
\cline { 2 - 6 } & $L_{s}$ & $W_{s}$ & $L_{q}$ & $W_{q}$ & \\
\cline { 2 - 6 } & 8,4 & 0,19 & 10,6 & 0,24 & \\
\hline
\end{tabular}

Berikut penjelasan hasil perhitungan analisis antrian menggunakan model M/M/S dengan 2 (dua) fasilitas loket Pendaftaran Akta Kelahiran di Disdukcatpil Kab. Karawang berdasarkan Tabel 3.

1) Tingkat Kegunaan Fasilitas $(\rho)$

Rata-rata tingkat kegunaan fasilitas pelayanan dalam melayani pendaftaran akta kelahiran pada jam 10.00 - 11.00 sebesar 100\% yang berarti cukup tinggi karena nilainya diatas 1 atau melebihi $100 \%$.

2) Peluang terdapat 0 orang dalam sistem $\left(\rho_{0}\right)$

Peluang tidak adanya pengunjung dalam sistem (pada jam 10.00 - 11.00) sebesar -0,04 atau kurang dari $0 \%$, artinya pengunjung pasti memasuki fasilitas pelayanan atau loket.

3) Jumlah pengunjung rata-rata dalam sistem (yang sedang menunggu untuk dilayani) $\left(L_{s}\right)$

Jumlah orang yang mengantri dalam sistem untuk dilayani (pada jam 10.00 - 11.00) yaitu sebanyak 8 orang.

4) Jumlah waktu rata-rata yang dihabiskan dalam sistem (waktu menunggu ditambah waktu pelayanan) $\left(W_{s}\right)$

Waktu rata-rata yang dihabiskan pengunjung untuk menunggu dalam sistem (pada jam 10.00 11.00) adalah 0,19 jam atau 5,3 menit.

5) Jumlah rata-rata yang menunggu dalam antrian ( $\left.L_{q}\right)$

Rata-rata jumlah pengunjung yang mengantri (pada jam 10.00-11.00) sebanyak 10,6 atau 11 orang.

6) Waktu rata-rata yang dihabiskan untuk menunggu dalam antrian $\left(W_{q}\right)$

Waktu rata-rata yang dihabiskan oleh pengunjung untuk menunggu dalam antrian (pada jam 10.00 11.00) adalah 0,24 jam atau 4,2 menit.

Berdasarkan uraian diatas, diketahui bahwa masalah sistem antrian yang ada di loket pendaftaran akta kelahiran Disdukcatpil Kab. Karawang adalah tingginya kedatangan orang dan tingginya waktu menunggu, hal ini terkait dengan jumlah fasilitas pelayanan loket sebanyak 2 (dua) fasilitas yang belum optimal.

Minimasi biaya merupakan salah satu tujuan dilakukannya analisis sistem antrian yang optimal pada loket pendaftaran akta kelahiran di Disdukcatpil Kab. Karawang. Dalam melakukan minimasi biaya, komponen yang diperhitungkan adalah biaya menunggu, biaya pelayanan, jumlah fasilitas loket dan jumlah orang dalam sistem.

1) Biaya Menunggu $\left(C_{w}\right)$

Komponen biaya menunggu merupakan biaya yang dikorbankan masyarakat dikarenakan mengantri di loket. Biaya total menunggu dapat diperkirakan berdasarkan pendapatan yang diterima oleh masyarakat per jam. Maka dari itu, sebagai acuan digunakan Upah Minimum Kota (UMK) Kabupaten Karawang berdasarkan Surat Keputusan Gubernur No. 561/kep1220-yanbangsos/2018 pada tahun 2019 yaitu sebesar Rp 4.234.010,- 
$C_{w}=$ Rp. $4.234 .010,-\div(8$ jam x 5 hari x 4 minggu $)$

$C_{w}=$ Rp. $26.462 / \mathrm{jam}$

2) Biaya Pelayanan $\left(C_{s}\right)$

Komponen biaya pelayanan yang timbul dalam antrian loket pendaftaran akta kelahiran di Disdukcatpil Kab. Karawang dihitung dengan menambahkan total gaji pegawai loket perbulannnya, dengan asumsi pegawai loket merupakan PNS golongan III-C yang telah bekerja selama kurang lebih sepuluh tahun, maka gaji pokok yang diterima perbulannya sebesar Rp. $3.272 .200,00$ berdasarkan PP No. 15 Tahun 2019.

Tabel 3. Hasil Perhitungan Biaya Pelayanan

Per Jam

\begin{tabular}{|l|l|}
\hline Jumlah loket & 2 \\
\hline Kompenen biaya & Gaji \\
\hline Biaya per-bulan & Rp. 3.272.200,- \\
\hline Jumlah & 2 \\
\hline Satuan & Orang \\
\hline Total & Rp. 6.544.400,- \\
\hline Total Per-jam & Rp. 40.902,-- \\
\hline
\end{tabular}

3) Jumlah Fasilitas Loket

Jumlah fasilitas loket untuk pendaftaran akta kelahiran sebanyak 2 (dua).

4) Jumlah orang dalam Sistem $\left(L_{s}\right)$

Berdasarkan tabel 4. jumlah orang dalam sistem sebanyak 15 orang.

Perhitungan biaya pendaftaran akta kelahiran untuk sistem antrian dengan 2 (dua) fasilitas loket adalah sebagai berikut.

$$
\begin{aligned}
& E\left(C_{t}\right)=E\left(C_{s}\right)+E\left(C_{w}\right) \\
& E\left(C_{t}\right)=M\left(C_{s}\right)+L_{s}\left(C_{w}\right) \\
& E\left(C_{t}\right)=2(R p .40 .902,-)+8,4(R p .26 .462,-) \\
& E\left(C_{t}\right)=R p .81 .804,-+R p .222 .280,- \\
& E\left(C_{t}\right)=R p .304 .085,-
\end{aligned}
$$

Perhitungan biaya total per bulan dengan 2 (dua) loket pelayanan (asumsi jam kerja dalam penelitian dan hari kerja selama 23 hari)

$=$ Rp. 304.085, $-\times 8 \mathrm{jam} \times 23$ hari

$=R p .55 .951 .603,-$

\section{Teori Antrian dengan lebih dari dua Fasilitas} Pelayanan (Setelah Simulasi)

Untuk mendapatkan kinerja yang lebih baik dan tingkat pelayanan yang optimal pada sistem antrian loket pendaftaran akta kelahiran di Disdukcatpil Kab. Karawang perlu dilakukan simulasi perhitungan berbagai tingkat kedatangan dengan menambah satu atau lebih dari satu fasilitas loket. Dalam mengembangkan model antrian berikut dibawah ini merupakan hasil perhitungan perbandingan sistem antrian untuk kedatangan menggunakan model $\mathrm{M} / \mathrm{M} / \mathrm{S}$ setelah simulasi penambahan 1 (satu) dan lebih dari 1 (satu) fasilitas loket pendaftaran akta kelahiran di Disdukcatpil Kab. Karawang. Berikut tabel perbandingan sistem antrian untuk loket pendaftaran akta kelahiran menggunakan model M/M/S dengan 3 (tiga) dan 4 (empat) fasilitas pelayanan pendaftaran akta kelahrian di Disdukcatpil Kab. Karawang.

Tabel 4. Perbandingan Sistem Antrian Loket Pendaftaran Akta Kelahiran (Kondisi Sebelum dan Setelah Simulasi)

\begin{tabular}{|l|l|l|l|}
\hline $\begin{array}{l}\text { Hasil } \\
\text { Perhitungan }\end{array}$ & $\begin{array}{l}2 \text { loket } \\
\text { (sebelum } \\
\text { simulasi) }\end{array}$ & $\begin{array}{l}3 \text { loket } \\
\text { (setelah } \\
\text { simulasi) }\end{array}$ & $\begin{array}{l}\text { loket } \\
\text { (setelah } \\
\text { simulasi) }\end{array}$ \\
\hline $\mathbf{M}$ & 2 & 3 & 4 \\
\hline $\boldsymbol{\lambda}$ & 44 & 44 & 44 \\
\hline $\boldsymbol{\mu}$ & 20 & 20 & 20 \\
\hline $\boldsymbol{P}$ & $100 \%$ & $74 \%$ & $55 \%$ \\
\hline $\boldsymbol{P}_{\mathbf{0}}$ & $-0,04$ & 0,13 & 0,32 \\
\hline $\boldsymbol{L}_{\boldsymbol{s}}$ & 8 & 4 & 3 \\
\hline $\boldsymbol{W}_{\boldsymbol{s}}$ & 11,4 & 5,03 & 3,38 \\
\hline $\boldsymbol{L}_{\boldsymbol{q}}$ & 11 & 2 & 1 \\
\hline $\boldsymbol{W}_{\boldsymbol{q}}$ & 14,4 & 2,03 & 0,38 \\
\hline
\end{tabular}

Minimasi biaya setelah simulasi

Perhitungan biaya pendaftaran akta kelahiran untuk sistem antrian dengan 3 (tiga) fasilitas loket adalah sebagai berikut.

$$
\begin{aligned}
& E\left(C_{t}\right)=E\left(C_{s}\right)+E\left(C_{w}\right) \\
& E\left(C_{t}\right)=M\left(C_{s}\right)+L_{s}\left(C_{w}\right) \\
& E\left(C_{t}\right)=3(R p .40 .902,-)+4(R p .26 .462,-) \\
& E\left(C_{t}\right)=R p .122 .706,-+R p .105 .848,- \\
& E\left(C_{t}\right)=R p .228 .554,-
\end{aligned}
$$

Perhitungan biaya total per bulan dengan 3 (tiga) loket pelayanan (asumsi jam kerja dalam penelitian dan hari kerja selama 23 hari)

$=R p .228 .554,-\times 8$ jam $\times 23$ hari

$=$ Rp. 42.053.936, -

Perhitungan biaya pendaftaran akta kelahiran untuk sistem antrian dengan 4 (empat) fasilitas loket adalah sebagai berikut.

$$
\begin{aligned}
& E\left(C_{t}\right)=E\left(C_{s}\right)+E\left(C_{w}\right) \\
& E\left(C_{t}\right)=M\left(C_{s}\right)+L_{s}\left(C_{w}\right) \\
& E\left(C_{t}\right)=4(R p .40 .902,-)+3(R p .26 .462,-) \\
& E\left(C_{t}\right)=R p .163 .608,-+R p .79 .386,- \\
& E\left(C_{t}\right)=R p .242 .994,-
\end{aligned}
$$

Perhitungan biaya total per bulan dengan 4 (empat) loket pelayanan (asumsi jam kerja dalam penelitian dan hari kerja selama 23 hari)

$=R p .242 .994,-\times 8$ jam $\times 23$ hari

$=R p .44 .710 .896,-$

3. Tingkat Optimalisasi yang diperoleh setelah menggunakan teori antrian di loket pendaftaran akta kelahiran Dinas Kependudukan dan Pencatatan Sipil Kabupaten Karawang

Berdasarkan hasil evaluasi perhitungan sistem antrian loket pendaftaran akta kelahiran di Disdukcatpil 
Kab. Karawang dengan kondisi aktual dan simulasi penggunaan jalur fasilitas pelayanan loket pendaftaran. Hasil perhitungan biaya total loket pendaftaran akta kelahiran di Disdukcatpil Kab. Karawang dengan kondisi optimal terdapat pada tabel 4.4 dibawah.

Tabel 5. Hasil Perhitungan Biaya Total Loket Pendaftaran Akta Kelahiran Dinas Kependudukan dan Pencatatan Sipil Kabupaten Karawang

\begin{tabular}{|l|ll|ll|l|}
\hline Indikator & \multicolumn{2}{|l|}{$\begin{array}{l}\text { Biaya Total } \\
\text { Per-bulan }\end{array}$} & \multicolumn{2}{|l|}{$\begin{array}{l}\text { Biaya Total } \\
\text { Per-jam }\end{array}$} & $\begin{array}{l}\text { Optimalis } \\
\text { asi }\end{array}$ \\
\hline $\begin{array}{l}2 \quad \text { loket } \\
\text { pelayanan } \\
\text { (sebelum } \\
\text { simulasi) }\end{array}$ & $\mathrm{Rp}$ & 55.951 .603 & $\mathrm{Rp}$ & $304.085,-$ & \\
\hline $\begin{array}{l}3 \quad \text { loket } \\
\text { pelayanan } \\
\text { (setelah } \\
\text { simulasi) }\end{array}$ & $\mathrm{Rp}$ & 42.053 .936 & $\mathrm{Rp}$ & $228.554,-$ & $75 \%$ \\
\hline $\begin{array}{l}4 \quad \text { loket } \\
\text { pelayanan } \\
\text { (setelah } \\
\text { simulasi) }\end{array}$ & $\mathrm{Rp} \quad 44.710 .896$ & $\mathrm{Rp}$ & 242.994 & \\
\hline
\end{tabular}

Berdasarkan tabel 6 diketahui bahwa biaya total untuk loket pelayanan pendaftaran akta kelahiran di Disdukcatpil Kab. Karawang pada bulan Juli 2019 dengan menggunakan 3 (tiga) loket lebih optimal dibandingkan dengan menggunakan 4 (empat) loket. Pada indikator biaya per-bulan maupun per-jam, penggunaan 3 (tiga) loket lebih rendah dibandingkan dengan menggunakan 4 (empat) loket. Jika dihitung selisih antara 3 (tiga) loket dan 4 (empat) loket, telah menghemat sebesar Rp. 2.656.960,-/ bulan dan Rp. 14.440,-/ jam.

Berikut grafik perbandingan biaya total loket pendaftaran akta kelahiran per-bulan dan per-jam sebelum simulasi (kondisi aktual) dan setelah simulasi pada bulan Juli tahun 2019.

\section{Biaya Total Per-Bulan}

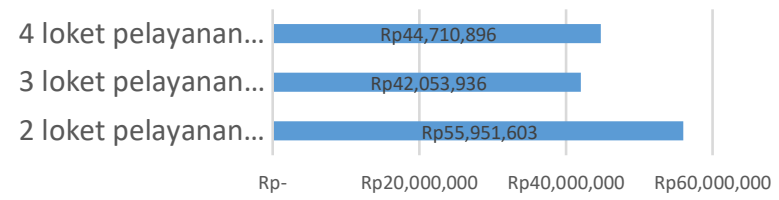

Gambar 7. Biaya Total per-Bulan Loket Pelayanan Pendaftaran Akta Kelahiran (Kondisi Aktual dan Simulasi)

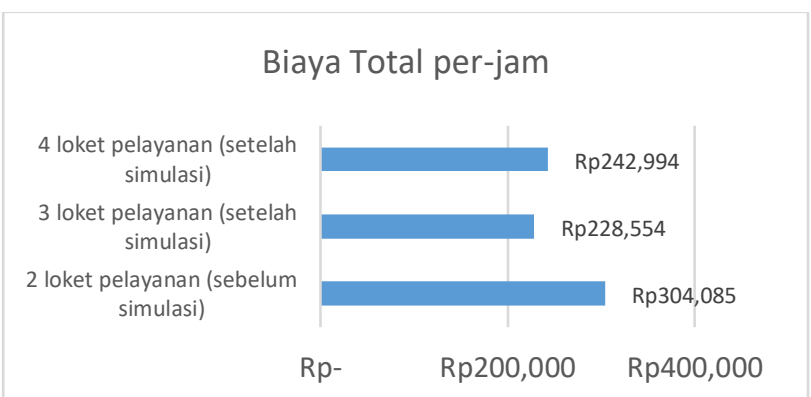

Gambar 8. Biaya Total per-Jam Loket Pelayanan Pendaftaran Akta Kelahiran (Kondisi Aktual dan Simulasi)
Berdasarkan gambar diatas, jenis loket yang optimal diterapkan pada loket pendaftaran akta kelahiran di Disdukcatpil Kab. Karawang tahun 2019 yaitu sebanyak 3 (tiga) loket dengan biaya total paling rendah yakni sebesar Rp. 347,739,632,-/ bulan dan Rp. 2,001,712,-/ jam. Berikut grafik biaya total loket pelayanan pendaftaran akta kelahiran di Disdukcatpil Kab. Karawang tahun 2019.

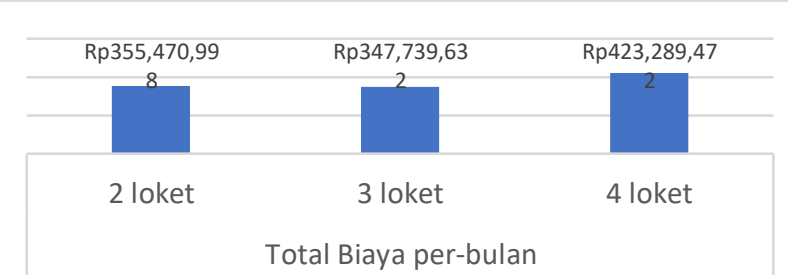

Gambar 9. Biaya Total per-bulan Tahun 2019 Loket Pelayanan Pendaftaran Akta Kelahiran

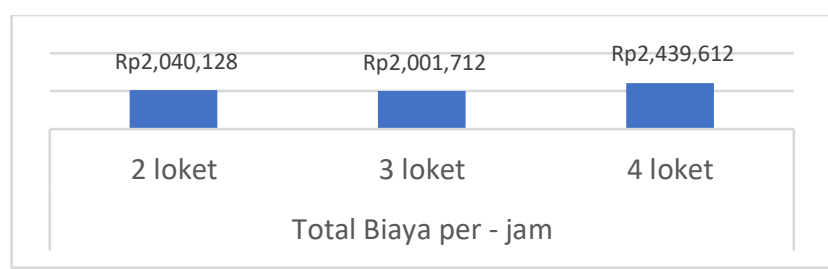

Gambar 10. Biaya Total per-Jam Tahun 2019 Loket Pelayanan Pendaftaran Akta Kelahiran

\section{Kesimpulan}

Hasil analisa yang telah dilakukan pada sistem antrian loket pendaftaran akta kelahiran di Dinas Kependudukan dan Pencatatan Sipil Kabupaten Karawang dapat disimpulkan :

1. Sistem antrian loket pendaftaran akta kelahiran di Dinas Kependudukan dan Pencatatan Sipil Kabupaten Karawang memiliki 2 (dua) jalur fasilitas yang beroperasi. Menerapkan disiplin antrian FCFS (First Come First Serve) dengan tingkat kedatangan $\left({ }^{\lambda}\right)$ berdistribusi poisson dan tingkat pelayanan $(\boldsymbol{\mu})$ menggunakan distribusi eksponensial. Adapun tingkat kedatangan yang lebih tinggi dibandingkan dengan tingkat pelayanan yang diberikan $(\lambda) \geq(\mu)$.

2. Sistem antrian loket pendaftaran akta kelahiran di Dinas Kependudukan dan Pencatatan Sipil Kabupaten Karawang dengan menggunakan metode antrian M/M/S memperoleh hasil bahwa jumlah jalur fasilitas pelayanan loket yang optimal yaitu sebanyak 3 (tiga) loket.

3. Tingkat optimalisasi yang diperoleh setelah menerapkan fasilitas sistem antrian yaitu sebesar 75\% menggunakan 3 loket.

\section{Rekomendasi}

Memilih objek penelitian dengan kondisi antrian yang lebih kompleks dan melakukan perbandingan antara 
perusahaan yang sudah menerapkan sistem antrian menggunakan teori antrian dengan yang belum memiliki sistem antrian terintegrasi.

\section{Daftar Pustaka}

Akhmad. (2018). Manajemen Operasi : Teori dan Aplikasi dalam Dunia Bisnis. Yogyakarta: Pustaka AQ, Azkiya Publishing.

Arum, P. R., Sugito, S., \& Wilandari, Y. (2014). Analisis Sistem Antrian Pelayanan Nasabah Bank X Kantor Wilayah Semarang. Jurnal Gaussian 3, 4, 791-800.

Botutihe, K., Sumarauw, J. S., \& Karuntu, M. M. (2018). Analisis Sistem Antrian Teller Guna Optimalisasi Pelayanan pada PT. Bank Negara Indonesia (BNI) 46 Cabang Unit Kampus Manado. EMBA, 6.

brs. (2013, November 22). Kementrian Komunikasi dan Informatika Republik Indonesia. Retrieved from https://kominfo.go.id/content/detail/3541/mend agri-mulai-1-januari-bikin-ktp-kk-dan-aktakelahiran-tidak-dipungut-biaya/0/berita

Budiasih, Y. (2015). Optimalisasi Kasir dan Minimasi Biaya Studi Kasus pada Swalayan PSFJ di Jakarta Selatan. Liquidity, 4, 53-63.

Heizer, J., \& Render, B. (2015). Manajemen Operasi : Manajemen Keberlangsungan dan Rantai Pasokan. Jakarta: Salemba Empat.

Krajewski, L. J., Malhotra, M. K., \& Ritzman, L. P. (2019). Operations management. Processes and supply chains. Boston: Pearson Education, Inc.

Mardalena, S. \&. (2017). Pengantar Manajemen. Deepublish.

Meflinda, A., \& Mahyarni. (2011). Operation Research (Riset Operasi). Riau: UR Press Pekanbaru.

Robbins, S. P., Coulter, M., Sabran, B., \& Hardani, W. (2010). Manajemen. Jakarta: Erlangga.

Septiadi, M. A. (2019). Strategi Kualiras Pelayanan pada Dinas Kependudukan dan Catatan Sipil Kota Bandung. Politicon : Jurnal Ilmu Politik, 72-87.

Sinaga, R., \& Sari, D. (2015). Analisis Sistem Antrian di DInas Kependudukan dan Pencatatan Sipil Kota Bandung. Jurnal Bina Ekonomi.

Sugiyono. (2012). Metode Penelitian Kuantitatif, Kualitatif dan R\&D. Bandung: Alfabeta CV. Bandung.

Syaifuddin, D. T. (2011). Riset Operasi (Aplikasi Quantitative Analysis for Management). Malang: CV Citra Malang. 